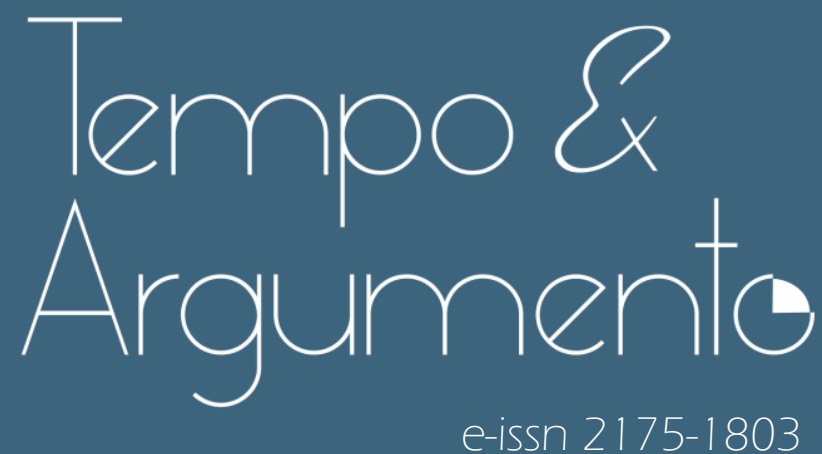

A mobilização das tópicas do pensamento social brasileiro na historiografia comercial consumida no Brasil em tempos de crise democrática (2013-2020)

- Rodrigo Perez Oliveira

Doutor em História Social pela Universidade Federal do Rio de Janeiro (UFRJ).

Professor do Programa de Pós-Graduação em História da Universidade

Federal Bahia (UFBA).

Salvador, BA - BRASIL

lattes.cnpq.br/8386419351011987

rodrigoperez@ufba.br

(D) orcid.org/0000-0002-9584-944X

Para citar este artigo:

OLIVEIRA, Rodrigo Perez. A mobilização das tópicas do pensamento social brasileiro na historiografia comercial consumida no Brasil em tempos de crise democrática (2013-2020). Tempo e Argumento, Florianópolis, v. 13, n. 33, e0204, maio/ago. 2021

doi http://dx.doi.org/10.5965/2175180313332021 e0204

Recebido: 16/03/2020

Aprovado: 20/02/2021 


\title{
A mobilização das tópicas do pensamento social brasileiro na historiografia comercial consumida no Brasil em tempos de crise democrática (2013-2020)
}

\begin{abstract}
Resumo
O objetivo deste artigo é examinar as interpretações do Brasil desenvolvidas nos livros que, evocando a identidade genérica historiográfica, encontraram grande sucesso no mercado editorial nesses anos de crise democrática. A hipótese do trabalho sugere que estes textos mobilizaram topos interpretativos produzidos pelos autores que aprendemos a chamar de "intérpretes do Brasil", que ao longo do século XX tentaram inventariar as causas do atraso brasileiro em ensaios de sínteses da história nacional. Ao final do texto, especulo a possibilidade de esses best-sellers da historiografia comercial terem colaborado para modular comportamentos políticos na sociedade civil na conjuntura da crise democrática ainda em curso no Brasil.
\end{abstract}

Palavras-chave: Pensamento social brasileiro; Signo do atraso; Historiografia comercial; Crise democrática.

\section{The mobilization of topics of Brazilian social thought in commercial historiography consumed in Brazil in times of democratic crisis (2013-2020)}

\begin{abstract}
The purpose of this article is to examine the interpretations of Brazil developed in books that, evoking the generic historiographical identity, found great success in the publishing market in these years of democratic crisis. The hypothesis of the work suggests that these texts mobilized arguments produced by the authors that we learned to call "interpreters of Brazil", who throughout the 20th century tried to inventory the causes of the Brazilian delay in synthesis essays of national history. At the end of the text, I speculate that these best-sellers of commercial historiography have collaborated to modulate political behavior in civil society in the context of the democratic crisis still underway in Brazil.
\end{abstract}

Keywords: Brazilian social thinking; Sign of delay; Commercial historiography; Democratic crisis.

\section{Introdução}

A história desde a época em que a escrita alfabética foi conhecida na Grécia até ao estado atual da espécie humana nos países esclarecidos da Europa é ligada por uma série ininterrupta de fatos e de observações. O espírito moderno, finalmente, descobriu que o quadro da marcha e dos progressos humanos é verdadeiramente histórico. (CARITAT, 1995, p. 18)

Marie Jean Antoine Nicolas de Caritat (1743-1794), o Marquês de Condorcet, foi um dos primeiros autores a verbalizar as transformações mentais que ao longo do século XVIII fundaram a cultura histórica moderna (BINOCHE, 1994). Tratando a 
A mobilização das tópicas do pensamento social brasileiro na historiografia comercial consumida no Brasil em tempos de crise democrática (2013-2020)

Rodrigo Perez Oliveira

história como o processo que caminharia do menos ao mais desenvolvido, das trevas à ilustração, Condorcet usou o termo "filosofia da história" para definir tanto os esforços da inteligência europeia em desvelar o sentido do devir histórico, como o movimento evolutivo inerente à própria história. Hans-Georg Gadamer chamou de "consciência histórica" esse gesto epistêmico que possibilitou ao "homem moderno" perceber que todo presente é transitório, que toda opinião é relativa a um dado contexto histórico (GADAMER, 2006). A história seria, então, uma série ininterrupta de fatos e observações em eterna marcha rumo ao progresso, entendido como telos universal (ARENDT, 1998; GUMBRECHT, 2010; KOSELLECK, 2006). Sendo dotada de racionalidade intrínseca, a história teria filosofia própria, manifestada nas forças motoras responsáveis pelo seu movimento. "Movimento": é essa a noção-chave mobilizada por Condorcet e que também pode ser encontrada em outros textos emblemáticos da modernidade produzidos ao longo dos séculos XVIII e XIX'.

As ideias de movimento e de progresso nos convidam a pensar em suas antíteses, como o "estático" e o "atraso". Somente faz sentido dizer que algo está "se desenvolvendo" se nos acharmos capazes de definir qual seria o estágio anterior, a "situação atrasada". Por mais que a modernidade europeia tenha sido eufórica com a real possibilidade do progresso ${ }^{2}$, não deixou de ser preocupar com

\footnotetext{
"Podemos citar aqui alguns autores canonizados como "clássicos" no pensamento político moderno. O "Manifesto Comunista", escrito por Friedrich Engels (1820-1885) e Karl Marx (1818-1883) e publicado em 1848, é atravessado pela ideia de "movimento". É o "movimento" que faz a humanidade superar o atraso pelo desenvolvimento constante das forças produtivas. Há momentos na história, dizem Engels e Marx, que esse movimento se acelera, chegando às vias da ruptura revolucionária. Foi isso que teria acontecido na Europa entre os séculos XVI e XVIII, quando a burguesia concluiu um "longo processo de desenvolvimento, de uma série de revoluções no modo de produção e de troca" (ENGELS; MARX, 1999, p. 10). Também no campo da filosofia política liberal, a ideia de "movimento" é basilar. Em autores como David Ricardo (1772-1823) e Adam Smith (1723-1790), o movimento histórico resolveria o dilema da pobreza material pela complementaridade produtiva (DARDOT; LAVAL, 2016). Já no evolucionismo de coloração darwinista de Herbert Spencer (1820-1903), o movimento da história extinguiria a pobreza material, eliminando os pobres, incapazes de sobreviver à dinâmica da competição social (GUERRA, 1998). Essa euforia não foi unânime, pois em diversas partes da Europa ecoaram vozes que desconfiaram do otimismo que caracterizou o projeto de modernidade que se tornou hegemônico nos séculos XVIII e XIX. Vindo da Escócia, o empirismo de David Hume (1711-1776) inspirou as diversas críticas à metafísica iluminista que foram desenvolvidas no espaço intelectual alemão ("idealismo alemão", em alguns manuais de história da filosofia), inspirando autores como Schopenhauer e Nietzsche (BEISER, 2002). Todos, de alguma forma, desconfiaram da euforia e do otimismo característicos do iluminismo francês. Também no espaço britânico, mais especificamente da Irlanda, se desenvolveu o conservadorismo de Edmund Burke (1729-1797), que seria apropriado na França por Tocqueville (1805-1859) e Chateaubriand (1768-1848). Já entre os alemães, o conservadorismo burkeano encontrou terreno fertilizado no tradicionalismo de Justus Moser (1720-1794), o que fez da Alemanha o centro do conservadorismo europeu moderno (MANNHEIM, 1987).
} 
A mobilização das tópicas do pensamento social brasileiro na historiografia comercial consumida no Brasil em tempos de crise democrática (2013-2020)

Rodrigo Perez Oliveira

as forças do atraso, que poderiam travar, ou pelo menos retardar, a tão esperada e cultuada marcha evolutiva da história. Nessa cosmovisão forjada inicialmente na Inglaterra e na França, o "atraso" é entendido como a sobrevivência das estruturas feudais, especialmente a fragmentação administrativa, o ruralismo e o misticismo religioso (CASSIRER, 1997).

Não é exagerado dizer, portanto, que as noções de movimento, progresso e atraso estruturam a modernidade, tendo sido espalhadas pelo mundo na esteira da dominação colonial que as potências europeias impuseram às outras regiões do planeta (MIGNOLO, 2008; QUIJANO, 1992). No caso específico da realidade brasileira, essa discussão foi ressignifica à luz da preocupação das elites políticas e intelectuais locais em viabilizar, e acelerar, o progresso nacional, o que significaria, por consequência lógica, a superação daquilo que era considerado o "atraso". O signo do atraso atravessa a história intelectual brasileira, tendo sido abordado em diferentes perspectivas, transformando-se no grande dilema existencial para aquilo que aprendemos a chamar de "pensamento social brasileiro". Meu objetivo neste artigo é mostrar que o interesse em discutir o "atraso nacional" ainda continua vivo entre nós, manifestado, sobretudo, nos livros de historiografia comercial ${ }^{3}$ que encontraram grande sucesso no mercado editorial nestes anos de crise democrática 4 .

\footnotetext{
Trato a noção de "historiografia comercial" à luz dos estudos desenvolvidos por Sara Albieri e Raquel Glezer. Segundo as autoras, o que distingue a historiografia profissional da historiografia amadora são os protocolos que autorizam os textos. Se a historiografia profissional é autorizada por um campo disciplinado relativamente autônomo a ponto de delimitar seus próprios procedimentos e interesses, as "obras fronteiriças" são autorizadas pelas preferências de um público que não tem compromisso com os protocolos que regem o conhecimento histórico disciplinado. Por isso, na prateleira de uma livraria comercial, é irrelevante se o texto foi escrito por um historiador profissional, se passou pelo crivo de uma banca avaliativa, se atende aos critérios de qualidade estabelecidos pela comunidade acadêmica. O que levaria o leitor não especializado a comprar determinado livro que ele entende pertencer ao gênero historiográfico seria a combinação entre "a propaganda efetivada pela indústria cultural e a expectativa de entretenimento e lazer (ALBIERI; GLEZER, 2009). Desenvolvi com mais cuidado a categoria "historiografia comercial" em trabalho anterior. Ver PEREZ, 2020.

4 Já existe uma bibliografia especializada que localiza em meados de 2013 o marco inaugurador da crise democrática ainda em curso no Brasil. Entre os autores que adotam essa delimitação cronológica, podemos citar: BRAGA, 2016 (BRAGA, Ruy. Terra em transe: o fim do lulismo e o retorno da luta de classes. In: LOUREIRO, Isabel; SINGER, André (orgs.). As contradições do lulismo. São Paulo: Boitempo, 2016. p. 55-92.); SINGER, 2013; MIGUEL, 2014 (MIGUEL, Luís Felipe. Democracia e representação: territórios em disputa. São Paulo: Ed. Unesp, 2014); PINHA, 2018 (PINHA, Daniel. Junho de 2013: crítica e abertura da crise da democracia representativa brasileira. Revista Maracanan, n. 8, 2018). No caso do trabalho de Wanderley Guilherme dos Santos, a ideia de que junho de 2013 é o marco inicial da crise é um tanto matizada, pois o autor argumenta que a desestabilização da democracia brasileira começou em 2005, episódio do "mensalão". Porém, o
} 
A mobilização das tópicas do pensamento social brasileiro na historiografia comercial consumida no Brasil em tempos de crise democrática (2013-2020)

Rodrigo Perez Oliveira

O texto está dividido em duas partes: primeiro, discuto a própria noção de "pensamento social brasileiro", explorando sua polissemia e, em diálogo com a bibliografia especializada, analisando como os mais notórios "intérpretes do Brasil" abordaram o tema do atraso nacional. Em seguida, me debruço sobre os bestsellers da historiografia comercial consumida no Brasil nos últimos anos, buscando entender como esses autores mobilizaram o signo do atraso nacional e atualizaram as teses desenvolvidas pelo ensaísmo de interpretação do Brasil.

\section{O signo do "atraso" no pensamento social brasileiro}

É pena que [Varnhagen] ignorasse ou desdenhasse o corpo de doutrinas criadoras que nos últimos anos se constituíram em ciência sob o nome de sociologia. Sem esse facho luminoso, ele não podia ver o modo porque se elabora a vida social. Sem ele, as relações que ligam os momentos sucessivos da vida de um povo não podiam desenhar-se em seu espírito de modo a esclarecer as diferentes feições e fatores reciprocamente. (ABREU, 1978, p. 507)

Todas as nossas grandes narrativas, produzidas no Império, na República ou na academia, repetiram com raríssimas exceções esse gesto inaugural do nosso pensamento político, e em todas elas a incompreensão do passado se associou a uma incapacidade de entender uma sociabilidade popular rebelde à imaginação liberal, republicana ou mesmo socialista. (BARBOZA FILHO, 2010, p. 18) A aceitação da filosofia eurocêntrica da história, que tornava a produção intelectual dotada de originalidade privativa das potências europeias, se refletiu, assim, na sua preferência pelo produto cultural oriundo daqueles países, em detrimento dos próprios, vistos invariavelmente como inferiores, precários, parciais, locais. ( $\mathrm{LYNCH}$, 2013, p. 744)

Desde os anos 1990, o termo "Pensamento social Brasileiro" é utilizado tanto para definir um conjunto de interpretações da realidade nacional, elaboradas entre o final do século XIX e meados do século XX, como para delimitar a identidade epistêmica de um determinado campo temático dentro dos estudos sociais

\footnotetext{
autor não nega a importância de junho de 2013, que segundo ele teria "acelerado a evolução da crise" (SANTOS, 2017). Em trabalho anterior, também me debrucei sobre um aspecto específico da crise democrática em curso no Brasil, relativo à força político/semântica de um certo significado do conceito corrupção. Ver: PEREZ, Rodrigo. O significado do conceito "corrupção" na semântica política da crise brasileira (2013-2016). Anos 90, Porto Alegre, v. 25, n. 48, p. 379-408, dez. 2018 e; PEREZ, Rodrigo. O engajamento político e historiográfico no ofício dos historiadores brasileiros: uma reflexão sobre a fundação da historiografia brasileira contemporânea (1975-1979). História da Historiografia: International Journal of Theory and History of Historiography, v. 11, n. 26, p. xx-xx, 29 abr. 2018
} 
A mobilização das tópicas do pensamento social brasileiro na historiografia comercial consumida no Brasil em tempos de crise democrática (2013-2020)

Rodrigo Perez Oliveira

universitários. Tendo eventualmente a noção de "pensamento político brasileiro" como sinônimo, o "pensamento social brasileiro" seria "o cânone de clássicos expressivos de uma teoria e/ou da velha ciência política brasileira, praticada por juristas, sociólogos e economistas antes da especialização universitária" (LYNCH, 2016, p. 75). Euclides da Cunha (1866-1909), Gilberto Freyre (1900-1987), Caio Prado Jr (1907-1990), Oliveira Vianna (1883-1951), Raimundo Faoro (1925-2003), Florestan Fernandes (1920-1995), Sérgio Buarque de Holanda (1902-1982) estão entre os “intérpretes do Brasil”, categoria forjada a posteriori pelas ciências sociais universitárias ${ }^{5}$.

Por outro lado, o "pensamento social brasileiro" também se tornou uma espécie de subcampo interdisciplinar dentro dos estudos sociais universitários, ocupado, principalmente, por sociólogos e cientistas políticos, já contando, inclusive, com seus próprios autores canônicos: Wanderley Guilherme dos Santos, Bolívar Lamounier, Christian Lynch, Gildo Marçal Brandão, Bernardo Ricupero, Rubem Barboza Filho, Luiz Werneck Vianna, José Murilo de Carvalho e Sérgio Miceli são referências incontornáveis nos estudos sobre o pensamento social brasileiro, sendo eles mesmos, também, intérpretes do Brasil, já que seus trabalhos estão

\footnotetext{
O ensaio sociológico de interpretação do Brasil teve seu valor heurístico progressivamente esvaziado pelas ciências sociais que na década de 1930 começaram a se instituir como disciplinas universitárias. Progressivamente, os ensaios sociológicos deixaram der ser vistos como textos relevantes para a compreensão da realidade e passaram a ser tratados como capítulos da história intelectual brasileira, espécie de prelúdio do "momento científico" que viria com a criação das universidades, nos anos 1930, e do sistema nacional de pós-graduação, a partir da década de 1970. Os ensaístas passaram a ser tratados como "intérpretes", em contraposição aos "cientistas" institucionalizados nas universidades e a "monografia científica" passou a ser vista como gênero textual prioritário dessas "ciências sociais", autodefinidas como epistemologicamente superiores. Sobre isso, ver: BOTELHO, André. Passado e futuro das interpretações do Brasil. Tempo Social, revista de sociologia da USP, [São Paulo], v. 22, n. 1, 2010.; PEREZ, Rodrigo. O significado do conceito "corrupção" na semântica política da crise brasileira (2013-2016). Anos 90, Porto Alegre, v. 25, n. 48, p. 379-408, dez. 2018 e; PEREZ, Rodrigo. O engajamento político e historiográfico no ofício dos historiadores brasileiros: uma reflexão sobre a fundação da historiografia brasileira contemporânea (1975-1979). História da Historiografia: International Journal of Theory and History of Historiography, v. 11, n. 26, p. XX-Xx, 29 abr. 2018; LESSA, Renato. Da interpretação à ciência: por uma história filosófica do conhecimento político no Brasil. Lua Nova, São Paulo, n. 82, p. 17-60, $2011 .$. Cronologicamente fora dessa "era do ensaismo", Florestan Fernandes nos leva a relativizar essa dicotomia "ensaismo X ciências sociais universitárias", como mostram Christian Lynch (2016) e Bernardo Ricupero (2011). Florestan Fernandes foi um dos principais responsáveis pela institucionalização das ciências sociais universitárias no Brasil, com todos seus protocolos metodológicos que questionaram a validade científica dos ensaios de interpretação. Mas foi também um dos mais destacados "ensaístas" da história das interpretações do Brasil, especialmente com o livro "A revolução burguesa no Brasil", publicado em 1975, no mesmo ano em que, por iniciativa do governo militar chefiado por Ernesto Geisel, se instituía no Brasil o sistema nacional de pós-graduação.
} 
A mobilização das tópicas do pensamento social brasileiro na historiografia comercial consumida no Brasil em tempos de crise democrática (2013-2020)

Rodrigo Perez Oliveira

longe de serem simples descrições das "ideias" dos "ensaístas". São, antes de tudo, esforços de interpretação da realidade nacional através dos textos representativos da "imaginação sociológica brasileira", para usar as palavras de Wanderley Guilherme dos Santos.

As epígrafes que abrem esta seção nos permitem explorar a polissemia da noção "pensamento social brasileiro", a começar pelo necrológico que Capistrano de Abreu (1853-1927) escreveu a Adolfo Varnhagen (1816-1878), o visconde de Porto Seguro, em 1878. Ambientado na "geração de 1870" (ALONSO, 2002), Capistrano de Abreu criticou a incapacidade de Varnhagen em pintar "um quadro geral, solidário e coerente da história brasileira". Demasiadamente interessado nos "assuntos sem importância, ou de importância secundária”, o visconde de Porto Seguro, apesar da "massa ciclópica" de documentos que reuniu em seu incansável trabalho de pesquisa, não teria conseguido escrever uma "história social” do Brasil capaz de colaborar com a modernização nacional, muito em virtude de sua ignorância em relação às novidades teóricas da "sociologia moderna”.

De alguma forma, Capistrano de Abreu estava dando contornos mais claros à agenda que seria assumida pela geração que chegaria à maioridade intelectual com a República, na transição do século XIX para o século XX. Não se tratava mais de tentar forjar, através do legalismo institucional, a unidade nacional, como foi o objetivo dos intelectuais envolvidos diretamente com a fundação do Estado brasileiro, como Bernardo Pereira de Vasconcelos (1795-1850) e Paulino José Soares de Sousa (1807-1866), o visconde de Uruguai. Tampouco se tratava de fomentar a identidade nacional, como foi posto como tarefa para os intelectuais atuantes no início do Segundo Reinado, entre os quais se destacam José de Alencar (1829-1877) e o já mencionado Francisco Adolfo de Varnhagen 6 . O objetivo passava a ser

\footnotetext{
- Apesar das autorrepresentações elaboradas pelos autores da época, Fábio Franzini (2011) adverte que é necessário algum cuidado antes de levarmos às últimas consequências a ideia de que os "ensaístas" romperam completamente com os valores epistemológicos da geração anterior. Fernando Nicolazzi chama atenção para o fato de que o ensaísmo pertence ao regime historiográfico da Primeira República, tendo sido alimentado por uma "experiência geracional de impasse e de desorientação temporal” (NICOLAZZI, 2016, p. 91). Porém, isso não quer dizer que a ruptura com o regime historiográfico anterior tenha sido total. $\mathrm{O}$ vínculo entre as duas gerações está, na interpretação de Nicolazzi, na busca pela síntese explicativa, cujas origens no Brasil remeteriam “à noção oitocentista de história filosófica, deslocando os elementos definidores da erudição histórica, constituídos com muito custo desde a geração fundadora do IHGB, cerca de um século antes" (NICOLAZZI, 2016, p. 92).
} 
A mobilização das tópicas do pensamento social brasileiro na historiografia comercial consumida no Brasil em tempos de crise democrática (2013-2020)

Rodrigo Perez Oliveira

"analisar cientificamente" a realidade brasileira, "com vistas a elaborar programas políticos de modernização e superação do atraso” (RICUPERO, 2011, p. 23).

Assim, de Euclides da Cunha a Florestan Fernandes, diversos autores tomaram o Brasil como objeto a ser explicado cientificamente, pretendendo compreender a ação das forças que bloqueavam o progresso nacional. Via de regra, esses autores utilizaram o ensaio como gênero discursivo prioritário, seguindo quase todos um mesmo padrão narrativo, começando por um grande balanço da história do Brasil e terminando com um projeto político sobre como superar os problemas do país (LAMOUNIER, 2007). Rubem Barboza Filho e Christian Lynch argumentam que, a despeito da diversidade de ideias elaboradas pelos "intérpretes", há, pelo menos, um fator comum à maioria deles: a relação agônica com o passado nacional, consequência da importação não mediada dos valores da cultura histórica europeia ${ }^{7}$, especialmente o ideal do progresso, entendido no velho mundo a partir de alguns signos, como urbanização, industrialização e organização institucionalmente nos moldes da democracia liberal burguesa.

Barboza Filho acusa a República, e Rui Barbosa (1849-1923), seu legislador original, de instituir uma leitura da história nacional que teria idealizado certo projeto de modernização que se tornou hegemônico na Europa durante o século XVIII e que definiu a consciência racional, baseada na "lógica do interesse", como superior à inconsciência emocional, marcada pela "lógica dos afetos". Toda a colonização e o período monárquico, regidos pela influência ibérica, deveriam ser superados pela República de inspiração anglo-saxã, o que teria gerado certo "déficit democrático" na cultura política republicana brasileira, algo que, ainda segundo Barboza Filho, foi denunciado por Euclides da Cunha já nos primeiros anos do século XX.

\footnotetext{
A crítica à importação não mediada dos valores da cultura histórica moderna já havia sido formulada antes, por autores inseridos na própria cultura intelectual ensaísta. O próprio Christian Lynch (2013) chama atenção para a atuação de Guerreiro Ramos, que quando na chefia do departamento de sociologia do ISEB, "combateu essa postura de rejeição integral do pensamento brasileiro pretérito por parte dos colegas. Guerreiro não discordava do caráter colonizado ou inautêntico do pensamento brasileiro, nem que ele estava em vias de emancipação em meados da década de 1950" (LYNCH, 2013, p. 753). Em perspectiva diferente no conteúdo, mas semelhante na forma, Lélia Gonzalez (1935-1994), completamente silenciada e excluída do pantheon dos intérpretes do Brasil, também criticou o hábito da importação não mediada dos repertórios cêntricos, tão comum à intelectualidade brasileira. Em texto publicado em 1984, a autora acusa a insuficiência do "marxismo clássico" em dar conta das especificidades do capitalismo brasileiro, que diferente do capitalismo europeu seria caracterizado, também, pela segregação racial.
} 
A mobilização das tópicas do pensamento social brasileiro na historiografia comercial consumida no Brasil em tempos de crise democrática (2013-2020)

Rodrigo Perez Oliveira

Ele [o Livro "Os sertões", de Euclides da Cunha] é o resultado da suspensão de todos os pressupostos das linguagens da razão e do interesse, e o fruto dessa percepção da autoprodução imanente do mundo e do homem. É a percepção do movimento da natureza, do espetáculo terrível e silencioso de sua formação, do desafio que ela lança ao homem para nela viver, obrigando-o a uma duríssima disciplina e à máxima solidariedade para viver e sobreviver. O que Euclides flagra na vida do sertanejo é esse exercício espontâneo da linguagem dos afetos [...] que o habilita a enfrentar não apenas a natureza, mas a civilização da razão e do interesse. (BARBOZA FILHO, 2010, p. 38)

A percepção é de que Euclides da Cunha teria influenciado "como um sopro libertador" um dos ramos mais importantes da literatura brasileira, reunindo Jorge Amado (1912-2001), José Lins do Rego (1901-1957), Graciliano Ramos (1892-1953), chegando ao auge com Guimarães Rosa (1908-1967). Nessa linhagem literária, o Brasil "expõe suas vísceras, a sua miséria provocada pelo andamento insensível de uma modernização que condena o povo à invisibilidade, e que simultaneamente registra a riqueza da vida popular, os sonhos dos homens comuns de um Brasil ainda rural" (BARBOZA FILHO, 2010, p. 38). Se formos seguir a trilha aberta por Barboza Filho, entenderemos que a República brasileira já nasce sendo objeto de, pelo menos, duas matrizes interpretativas, cada uma tendo sua própria leitura do "atraso nacional".

De um lado, a leitura do liberalismo anglófono, que fundada na "linguagem do interesse" pintou o passado colonial (incluindo a Monarquia) como a origem do atraso, visto que assentado em valores arcaicos cuja sobrevivência bloquearia a modernização nacional. Seria necessário, então, importar instituições “modernas", anglo-saxãs, para que elas tivessem efeito pedagógico na sociedade, educando costumes no sentido da construção de uma "verdadeira civilização moderna". Do outro lado, há a crítica a esse ideário de modernização, desenvolvida inicialmente por Euclides da Cunha e levado às últimas instâncias por Guimarães Rosa, que localiza não na colonização e na Monarquia a origem do atraso, mas sim na própria Proclamação da República, tratada como resultado de uma conspiração de elites que tentou forjar um "povo" a partir de valores estranhos à sua realidade. Nessa perspectiva, a República já nasce maculada por um vício de origem. Ao apresentar a história intelectual republicana nesses termos, Barboza Filho toma partido na disputa, também ele interpretando o Brasil e propondo uma agenda para o país: o 
A mobilização das tópicas do pensamento social brasileiro na historiografia comercial consumida no Brasil em tempos de crise democrática (2013-2020)

Rodrigo Perez Oliveira

desenvolvimento nacional passaria por um reencontro com nossas "tradições afetivas" e pela superação do "atraso", entendido como o fetichismo com o liberalismo anglófono, característico da "República dos bacharéis" instituída em 1889.

Christian Lynch está interessado em denunciar as práticas de colonização epistêmica que, em sua percepção, restringiram a limites muito estreitos as ambições dos intelectuais brasileiros. Buscando inspiração na discussão proposta inicialmente por Leo Strauss, Lynch trata da distinção, usual nos estudos políticos, entre "teoria ou filosofia política" e "pensamento ou história das ideias políticas". Os textos "teóricos ou filosóficos" seriam "coerentes, abrangentes e abstratos", enquanto o "pensamento político" seria "fragmentário, circunstancial e contingente". A distinção tem dimensão valorativa e hierarquiza os autores dedicados às questões políticas. O "teórico ou filósofo" seria contemplativo e capaz de abordar dilemas universais, existenciais, legando, assim, uma "teoria”, ou “filosofia”, que tem a pretensão de ser válida em quaisquer condições em que existam seres humanos vivendo em coletividade. Nesse conjunto de autores estariam John Locke (1632-1704), Jean-Jacques Rousseau (1712-1778), Thomas Hobbes (1588-1689), Karl Marx, entre outros.

Já o "pensador" estaria mais comprometido com a prática, com as circunstâncias específicas da vida política em que está diretamente inserido, com a resolução dos problemas que afetam sua comunidade. Assim, o "pensamento "político" teria pouca utilidade fora do seu espaço nativo. Lynch argumenta que essa hierarquia é o resultado das relações assimétricas estabelecidas na modernidade, que criaram uma divisão social do trabalho intelectual na qual Europa e os EUA são o centro da inteligência, enquanto as outras regiões são a periferia. Vivendo sob circunstâncias sociais e políticas mais evoluídas, os intelectuais europeus teriam encontrado condições propícias que lhe permitiram a contemplação desinteressada e a consequente formulação de teorias de valor universal. Já os "intelectuais periféricos", vivendo em sociedades atrasadas, precisavam se debruçar sobre suas especificidades locais, inclusive para colaborar com o desenvolvimento regional, sempre com o objetivo, é claro, de chegar ao mesmo estágio evolutivo no qual já estariam as "sociedades centrais". É por isso 
A mobilização das tópicas do pensamento social brasileiro na historiografia comercial consumida no Brasil em tempos de crise democrática (2013-2020)

Rodrigo Perez Oliveira

que as elites intelectuais brasileiras, internalizando essa hierarquia epistêmica, "sempre consideraram seus produtos mais ou menos inferiores àqueles desenvolvidos na Europa e nos Estados Unidos, em consequência de uma percepção mais ampla do caráter periférico do seu país” (LYNCH, 2013, p. 730-731).

Lynch não apenas acusa a subalternidade das elites intelectuais brasileiras, mas também elabora uma interpretação do Brasil e um diagnóstico a respeito do atraso nacional. Na sua crítica intelectual, o autor sugere que o atraso ganha forma nos equívocos de um certo pensamento social que, maculado pelo "fantasma da condição periférica", não conseguiu inspirar as elites dirigentes com ideias capazes de fomentar projetos de desenvolvimento social adequados às particularidades brasileiras. A superação do atraso começaria com a emancipação cognitiva a partir da qual os intelectuais brasileiros, se reconhecendo como pertencentes a uma comunidade semântica ibero-americana, se tornassem capazes de relativizar o "regime eurocêntrico de historicidade", compreendendo que cada sociedade possui necessidades específicas que devem ser compreendidas, e que nenhuma cultura intelectual tem a prerrogativa da universalidade.

O primeiro movimento dessa emancipação teria acontecido, ainda que de forma um tanto pálida, entre as duas guerras mundiais, com o "paradigma cultural nacionalista", que "desencadeou no subcontinente [a América Ibérica] uma mudança importante no modo de conceber o lugar dos países periféricos no mundo e de aferir a qualidade da sua produção cultural” (LYNCH, 2013, p. 745). Os intelectuais ibero-americanos possuíam, agora, um repertório que thes permitia criticar as concepções evolucionistas unilineares, matizando a crença na universalidade dos modelos, "avançando, em seu lugar, a tese de que cada país possuía uma trajetória própria; que não havia linearidade, mas pluralidade das linhas de evolução nacional” (LYNCH, 2013, p. 745). Estava aberta a brecha pela qual passaram alguns dos mais importantes intelectuais brasileiros como Oliveira Vianna e Gilberto Freyre, que rejeitaram o topos da autodepreciação, e Guerreiro Ramos (1915-1982), que formulou com clareza a crítica à colonização intelectual, vaticinando que a inteligência brasileira estava em vias de emancipação na década de 1950. 
A mobilização das tópicas do pensamento social brasileiro na historiografia comercial consumida no Brasil em tempos de crise democrática (2013-2020)

Rodrigo Perez Oliveira

Na genealogia traçada por Lynch, esse movimento de emancipação intelectual teria sido interrompido em 1964, com o golpe que implementou a ditadura entre nós, levando parte da intelectualidade brasileira a direcionar os esforços de interpretação da realidade à denúncia do autoritarismo dos governos militares. Somente nos anos 1980, as críticas ao eurocentrismo encontrariam ambiente para pleno desenvolvimento, destacando-se aqui a figura de Wanderley Guilherme dos Santos, o "pensador da democracia brasileira". Lynch se vê como herdeiro desse processo de emancipação intelectual, e como representante de um pensamento político que, não se considerando subalterno, toma para si a agenda de colaborar para o aprimoramento da democracia brasileira, levando em conta as especificidades de nossa existência nacional.

Também Gildo Marçal Brandão (2005) nos ajuda a entender as diversas leituras do atraso nacional que tiveram lugar ao longo da história intelectual brasileira, sem deixar de desenvolver a sua própria interpretação do Brasil. Retomando o projeto inicialmente formulado por Oliveira Vianna de classificar os pensadores brasileiros em "linhagens", o autor nos apresenta quatro grupos distintos, e quatro formas diferentes de mobilizar o signo do atraso. Primeiro, Brandão fala em um "idealismo orgânico", cujo autor paradigmático é Oliveira Vianna, para quem a matriz do atraso é a situação de anomia e fragmentação herdadas da colonização. Para avançar no sentido da integração nacional, seria necessária a ação do Estado, mas não o Estado construído a partir de instituições importadas da Europa e dos EUA. O Estado que deveria agir como tutor do progresso nacional, na percepção dos autores que Brandão inventaria como pertencentes ao "idealismo orgânico", e que conta ainda com nomes como Alberto Torres (1865-1917) e Visconde de Uruguai; é o "Estado orgânico", edificado a partir dos sentimentos e valores "intrínsecos ao povo brasileiro", como costumava dizer o próprio Oliveira Vianna.

Em seguida, Brandão destaca o "idealismo constitucional", linha de pensamento imediatamente rival ao "idealismo orgânico" e identificada com autores de matriz ideológica liberal, como Tavares Bastos (1839-1875) e Rui Barbosa. Partindo de premissa semelhante aos "idealistas orgânicos", o "idealismo constitucional" também acusava a colonização ibérica de deixar como herança uma 
A mobilização das tópicas do pensamento social brasileiro na historiografia comercial consumida no Brasil em tempos de crise democrática (2013-2020)

Rodrigo Perez Oliveira

sociedade civil desarticulada e incapaz de, por si só, fazer valer seus direitos fundamentais. Da mesma forma como fizeram os "idealistas orgânicos", os “idealistas constitucionais" também viram no Estado o único meio possível de superação do atraso. As diferenças, que não são pequenas, estão no tipo de Estado idealizado e na utopia a ser alcançada. Os "idealistas constitucionais" acreditavam que seria necessária a importação de instituições pertencentes à cultura jurídica anglófona. Em um primeiro momento, o modelo emulado foi a monarquia inglesa. Depois, foi a República estadunidense. Nos dois casos, estava a convicção de que as instituições, no Brasil, deveriam agir pedagogicamente no sentido de fomentar costumes virtuosos na população, entendendo "virtude" como adesão aos preceitos liberais.

Gildo Marçal Brandão argumenta que tanto o "idealismo constitucional" como o "idealismo orgânico" são sistemas de pensamento aristocráticos que traduzem os interesses das "elites da terra". Em contraposição a essas linhagens, ganharam forma, ainda segundo o autor, outras "constelações de ideais", de natureza política mais "libertária e progressista”. Seriam essas o "radicalismo de classe média”, formulação que Brandão buscou em Antônio Candido (1918-2017), e o "marxismo de matriz comunista", que a partir da década de 1950 apostou no projeto da "revolução dentro da ordem", acreditando na real possibilidade de que, no Brasil, o desenvolvimento do capitalismo não era incompatível com a democracia. Diz Brandão que o "radicalismo de classe média" envolveu a maior parte dos socialistas e comunistas e se cristalizou a partir dos anos 1940 e 1950, especialmente na Universidade de São Paulo" (BRANDÃO, 2005, p. 240), encontrando em Florestan Fernandes e Fernando Henrique Cardoso seus principais representantes. O objetivo dessa linhagem não seria, exatamente, promover a revolução social no Brasil, vista como impossível àquela altura, mas sim apresentar aos atores políticos um "pensamento democrático socializante, quase sempre liberal, por vezes constitucionalista". Diferente era o caso do "marxismo de matriz comunista”, que encontrou no Partido Comunista Brasileiro (PCB) seu centro de articulação, e em Nelson Werneck Sodré (1911-1999) e Caio Prado Júnior seus principais articuladores. 
A mobilização das tópicas do pensamento social brasileiro na historiografia comercial consumida no Brasil em tempos de crise democrática (2013-2020)

Rodrigo Perez Oliveira

Analiticamente, o que caracteriza essa linhagem é a busca "bem ou malsucedida, de encontrar a unidade entre, digamos, a infra e a superestrutura na explicação do social” (BRANDÃO, 2005, p. 241). Com diferenças importantes entre si, o "radicalismo de classe média" e o "marxismo de matriz comunista" localizaram na construção do capitalismo periférico brasileiro a matriz do atraso nacional. Superar o atraso significaria transformar estruturalmente o capitalismo brasileiro, fosse rompendo com ele através da ação revolucionária, fosse reformando-o "por dentro", tendo como tática a construção de frentes amplas com a "burguesia nacionalista".

O que fica claro nos textos de Brandão é que seu objetivo não é apenas desenvolver uma taxonomia do ecossistema intelectual brasileiro, mas sim elaborar uma espécie de sociologia intelectual de inspiração marxista, em que as ideias de nossos principais pensadores são vinculadas a macroprojetos políticos. Pensamento e ação estão tão articulados no pensamento político de Brandão que ele chega a se perguntar, em texto publicado em 1998 se, de fato, "existe uma teoria política”. Por um lado, as ideias políticas não são tratadas pelo autor como substâncias etéreas, que pairam acima dos "processos políticos reais". Tampouco, as "ações" são o resultado de simples intuição dos agentes políticos, como se não existissem repertórios moduladores de comportamento agindo à revelia da consciência dos próprios sujeitos.

É a partir dessas premissas teóricas que podemos perceber o projeto intelectual e político de Brandão: traçar as grandes linhagens do pensamento político brasileiro, relacionando-as ao processo político e lançando luz sobre suas manifestações na contemporaneidade, especialmente em projetos que disputaram entre si qual deveria ser o centro planejador do desenvolvimento nacional, se o Estado ou o mercado. Seria possível ler nessa chave os conflitos travados entre PT e PSDB durante a IV República brasileira? A corrente política que recentemente começamos a chamar de "bolsonarismo" teria alguma ancestralidade nessas grandes linhagens do pensamento político brasileiro? Brandão, morto em 2010, não desenvolveu essas questões, que ainda estão aí, abertas no debate político nacional. 
A mobilização das tópicas do pensamento social brasileiro na historiografia comercial consumida no Brasil em tempos de crise democrática (2013-2020)

Rodrigo Perez Oliveira

Ainda haveria muito a ser dito sobre as interpretações do Brasil desenvolvidas pelos "intérpretes dos intérpretes". Poderíamos enveredar, por exemplo, pela leitura liberal da história intelectual brasileira desenvolvida por Boliva Lamounier, que confrontou aquilo que chamou de "pensamento autoritário" com o objetivo de reabilitar Rui Barbosa da crítica de artificialismo institucional. Ou mesmo dedicar mais atenção ao pensamento político democrático de Wanderley Guilherme dos Santos, que teve a oportunidade de examinar a crise democrática iniciada em 2013 e ainda em curso no momento em que escrevo este artigo. Mas a economia do texto não me permite dedicar mais espaço a esse grupo de autores, e nem é esse meu objetivo, não aqui. Estou mesmo interessado nas formas recentes de mobilização dessas teses de interpretação do Brasil ${ }^{8}$, especialmente no que se refere aos best-sellers da historiografia comercial.

\section{O signo do atraso nos best-sellers da historiografia comercial brasileira contemporânea}

No processo de fabricação de um espírito nacional, é normal que se inventem tradições, heróis, mitos fundadores e histórias de chorar, que se jogue um brilho a mais em episódios que criam um passado em comum para todos os habitantes e provocam uma sensação de pertencimento. Se este país quer deixar de ser café com leite, um bom jeito de amadurecer é admitir que alguns dos heróis da nação eram picaretas ou pelo menos pessoas do seu tempo. (NARLOCH, 2009, p. 06)

Por conta disso, temos que examinar de que modo a interpretação dominante do país ajudou e pavimentou o trabalho sujo da mídia de distorção sistemática da realidade. Sem essa ajuda dos intelectuais mais respeitados entre nós, que produziram uma interpretação falsamente crítica da nossa realidade, a mídia não poderia ter feito esse trabalho de modo tão fácil, que penetrou tão profundamente no imaginário da população. (SOUZA, 2017, p. 13)

Leandro Narloch e Jessé Souza são autores dos livros que estiveram entre os principais sucessos na história recente do mercado editorial brasileiro. O "guia politicamente incorreto da História do Brasil", publicado em 2010, esteve no topo

\footnotetext{
${ }^{8}$ Há diversos outros suportes materiais de atualização das tópicas do pensamento social brasileiro. O trabalho de Esther Hamburger (2011) mostra como as teses formuladas originalmente pelos "intérpretes" foram apropriadas nos roteiros das televonelas que marcam a história da televisão brasileira. Já Christian Lynch (2016) afirma que algumas dessas tópicas estão diluídas no jornalismo político, especialmente em nomes como Merval Pereira e Reinaldo Azevedo.
} 
A mobilização das tópicas do pensamento social brasileiro na historiografia comercial consumida no Brasil em tempos de crise democrática (2013-2020)

Rodrigo Perez Oliveira

da lista dos mais vendidos na categoria "não ficção" entre fevereiro e março de 2014, enquanto o "A elite do atraso", de Jessé Souza, esteve na posição em novembro de 2017, voltando a ocupá-la em janeiro e junho de 20189. Em outro lugar (PEREZ, 2020), examinei os enunciados discursivos mobilizados pelos autores e que nos ajudam a entender o sucesso comercial que alcançaram. Agora, quero mostrar como o signo do atraso foi mobilizado nas páginas desses textos.

Com todas as diferenças ideológicas que fizeram de Narloch e Souza os autores prediletos, respectivamente, da direita e da esquerda brasileiras contemporâneas, há entre eles algumas semelhanças naquilo que se refere ao procedimento adotado para identificar, e denunciar, as causas do atraso nacional. Eles compartilham a premissa teórica de que não existe dicotomia entre pensamento e ação política, de que todo pensamento é o resultado de um conjunto de interesses políticos práticos e que toda ação política é modelada por linhagens de pensamento. Nesse sentido, ao criticar a "historiografia politicamente correta" e os "viralatismo dos intelectuais uspianos", Leandro Narloch e Jessé Souza, respectivamente, abordam o atraso nacional a partir de um exercício de crítica intelectual.

É hora de jogar tomates na historiografia politicamente correta. Este guia reúne histórias que vão diretamente contra ela. Só erros das vítimas e dos heróis da bondade, só virtudes dos considerados vilões. Alguém poderá dizer que se trata do mesmo esforço dos historiadores militantes, só que na direção oposta. É verdade. Quer dizer, mais ou menos. Este livro não quer ser um falso estudo acadêmico, como o daqueles estudiosos, e sim uma provocação. Uma pequena coletânea de pesquisas históricas sérias, irritantes e desagradáveis, escolhidas com o objetivo de enfurecer um bom número de cidadãos. (NALORCH, 2009, p. 3)

Este livro foi pensado para ser uma leitura historicamente informada da conjuntura recente brasileira. A crise brasileira atual é também, e antes de tudo, uma crise de ideias. Existem ideias velhas que nos legaram o tema da corrupção na política como o grande problema nacional. Isso é falso, embora como toda mentira e toda fraude, tenha seu pequeno grau de verdade. Nossa corrupção real, a grande fraude que possibilita o resgate do Brasil esquecido e humilhado, está em outro lugar e é construída por outras forças. São essas forças, tornadas invisíveis para melhor exercerem o poder real, que o livro pretende desvelar. (SOUZA, 2017, p. 7)

${ }^{9}$ Utilizo aqui os dados disponibilizados pelo site publishnews e pelas Livrarias Amazon e Saraiva, principais empresas de e-commerce em atuação no Brasil. 
A mobilização das tópicas do pensamento social brasileiro na historiografia comercial consumida no Brasil em tempos de crise democrática (2013-2020)

Rodrigo Perez Oliveira

2010 e 2017: sete anos separam a publicação dos dois livros. Narloch escreveu sob os governos comandados pelos Partido dos Trabalhadores (PT), quando a aprovação popular de Luiz Inácio Lula da Silva batia recorde, chegando a 87\%, o que the permitiu eleger sua sucessora, Dilma Rousseff, com relativa facilidade. O sucesso das administrações petistas se explicava, sobretudo, pelas políticas públicas compensatórias baseadas na ideia de que o Estado brasileiro possuía uma "dívida histórica" com determinados grupos sociais, como mulheres, pessoas pretas, indígenas e pobres em geral. Para Narloch, a mentira está exatamente aqui, na noção de "dívida histórica", que retirada diretamente da “historiografia marxista militante", produzida entre as décadas de 1970 e 1980, estava sendo usada pelos governos petistas para se perpetuarem no poder.

Entre esses "historiadores militantes", Narloch destaca Décio Freitas (19222004), Joel Rufino dos Santos (1941-2015) e Clovis Moura (1925-2003), que representando os interesses do movimento negro em ascensão na época "fizeram do líder negro [Zumbi dos Palmares] do século 17 um representante comunista que dirigia uma sociedade igualitária" (NARLOCH, 2010, p. 48). O objetivo dessa historiografia seria contar a história do Brasil na chave do conflito, como se fosse uma manifestação local do princípio universal da luta de classes, formulado por Marx e Engels no século XIX. Para Narloch, o equívoco não se explica por simples inépcia metodológica, mas sim por um projeto deliberado de falseamento do passado que pretendia garantir privilégios para alguns grupos na dinâmica da competição social.

Já Jessé Souza escreveu sob circunstâncias completamente diferentes. O petismo já havia sido derrubado do governo em 2016, em impeachment controverso e definido como "golpe" por parte da crítica especializada. Lula era alvo de diversas acusações de corrupção, o que culminou em sua prisão, em abril de 2018, em processo penal com legitimidade questionada na comunidade jurídica nacional e internacional ${ }^{10}$. O petismo estava em baixa, rejeitado por amplos setores da sociedade civil, acusado de ter organizado o mais sofisticado esquema de corrupção já visto no país. O objetivo de Jessé Souza é criticar a narrativa de

\footnotetext{
10 Ver: COSTA, Álvaro Augusto; MALHEIROS, Antônio Carlos et al. O caso Lula: a luta pela afirmação dos direitos fundamentais no Brasil. São Paulo: Editora Geral, 2016.
} 
A mobilização das tópicas do pensamento social brasileiro na historiografia comercial consumida no Brasil em tempos de crise democrática (2013-2020)

Rodrigo Perez Oliveira

interpretação do Brasil que funda semanticamente o antipetismo e alimenta o "lavajatismo"11. Segundo essa narrativa, profundamente capilarizada no imaginário coletivo, a corrupção, praticada dentro do aparelho do Estado, é a fonte dos males que até hoje atrasam o desenvolvimento nacional. O autor argumenta que essa tese foi formulada originalmente pelas "vacas sagradas" do pensamento social brasileiro, começando por Sérgio Buarque de Holanda e chegando até Roberto Da Matta, passando por Raymundo Faoro e Fernando Henrique Cardoso. Esses autores, diz Jessé Souza, endossaram a tese do "patrimonialismo" e, com isso, demonizaram o Estado, mascarando aquele que, de fato, seria o grande responsável pelos nossos males: o passado escravocrata.

Como podemos perceber, tanto Leandro Narloch como Jessé Souza apresentaram aos seus milhares de leitores o argumento de que a crise brasileira é, antes de qualquer coisa, uma crise de ideias. O atraso se manifestaria, então, em interpretações equivocadas da realidade que acabaram por inspirar práticas políticas igualmente equivocadas. Mas seria possível corrigir os rumos, desde que se corrigissem, antes, as ideias. Essa correção, segundo Narloch, já estaria sendo feita desde a década de 1990, e pela própria historiografia universitária, que em um giro antimarxista protagonizado por autores como Warren Dean, John Monteiro, Maria Regina Celestino de Almeida, Manolo Florentino, João José Reis e Daniel Aarão Reis, teria deixado claro que a dicotomia "pobre X rico" não explica a história nacional, que seria marcada muito mais pela negociação e acomodação de interesses do que pelo conflito.

Para Narloch, esses historiadores mostraram que Índios também predaram o patrimônio natural e que a escravidão não foi tão cruel assim, permitindo, inclusive, que escravos acumulassem riquezas e comprassem outros escravos, que os grupos envolvidos na luta armada durante a ditadura não tinham compromisso com a democracia, mas sim com "autoritarismos de esquerda”. Leandro Narloch,

\footnotetext{
11 Termo que costuma ser usado para definir o movimento político que nasceu no Paraná, em março de 2014, sob a liderança de alguns membros do poder judiciário, como Sérgio Moro e Deltan Dallagnol. Em outro espaço, analisei com mais cuidado a semântica política lavajatista, mostrando como a Operação Lava-Jato se tornou "sucesso de público e crítica" indo ao encontro de uma interpretação do Brasil que, desde o final da década de 1980, associava a corrupção à coisa pública, como se o Estado fosse naturalmente corrupto e corruptor. Ver PEREZ, Rodrigo., 2018.0 significado do conceito "corrupção" na semântica política da crise brasileira (2013-2016). Anos 90, Porto Alegre, v. 25, n. 48, p. 379-408, dez. 2018
} 
A mobilização das tópicas do pensamento social brasileiro na historiografia comercial consumida no Brasil em tempos de crise democrática (2013-2020)

Rodrigo Perez Oliveira

portanto, situa seu "Guia Politicamente Incorreto da História do Brasil" em um movimento de superação do marxismo que estaria em marcha já há algum tempo dentro da universidade brasileira. Também Jessé Souza arrola seus aliados na luta contra a "tese do patrimonialismo", destacando autores que não teriam se deixado levar pelo "viralatismo" formulado pelos "uspianos". Entre as referências mobilizadas estão nomes importantes dos estudos sociais brasileiros, como Gilberto Freyre e Darcy Ribeiro (1922-1997), e referências da cena artística nacional, como Glauber Rocha (1939-1981), Jorge Mautner e Caetano Veloso.

Lilia Schwarcz é outro best-seller que se dedicou ao problema do atraso nacional, se apropriando diretamente de algumas teses formuladas pelos "intérpretes do Brasil". A autora frequentou a lista dos mais vendidos em duas ocasiões: com o "Brasil, uma biografia" (2017), que assinou junto com Heloísa Starling, e com o "Sobre o autoritarismo brasileiro" (2019), que foi o top one em outubro de 2019.

O bovarismo nacional faz par com outra característica que tem nos definido enquanto nacionalidade: o "familismo", ou o costume arraigado de transformar questões públicas em questões privadas. Entre nós, o bom político é um familiar, poucas vezes chamado pelo sobrenome, já que é mais reconhecido pelo primeiro nome ou por um apelido: Dilma, Jango, Juscelino, Lula, Getúlio. [...] Conforme propôs Sérgio Buarque de Holanda, o país foi sempre marcado pela precedência dos afetos e do imediatismo emocional sobre a rigorosa impessoalidade dos princípios que organizam usualmente a vida dos cidadãos nas mais diversas nações. (SCHWARCZ; STARLING, 2017, p. 17)

O povo costumava cumprimentá-los [os senhores] com reverência, chamando-os por apelidos, pelo primeiro nome ou até pelo diminutivo deste. Se tais práticas denotavam proximidade, ao mesmo tempo sublinhavam o respeito pelos mores paternalistas que se foram enrijecendo na área rural. Ou seja, o uso da "intimidade" apenas encobria hierarquias estáveis de poder. É esse, aliás, o argumento do historiador Sérgio Buarque de Holanda, que em seu livro "Raízes do Brasil" (1936) comentou o uso disseminado desses expedientes como forma de misturar relações públicas e privadas e guardar uma certa proximidade que disfarça o real e estrita distância social. (SCHWARCZ, 2019, p. 46)

No "Brasil, uma biografia”, Lilia Schwarcz e Heloísa Starling mobilizam a alegoria da biografia para sugerir que o Brasil é dotado de uma "subjetividade", de um traço de temperamento que atravessaria a história do país. Inspiradas em Lima Barreto e Sérgio Buarque de Holanda, as autoras argumentam que o "bovarismo" 
A mobilização das tópicas do pensamento social brasileiro na historiografia comercial consumida no Brasil em tempos de crise democrática (2013-2020)

Rodrigo Perez Oliveira

estaria entre as mais perniciosas "manias nacionais", consistindo em uma distorção de autoimagem, pois ao se "olhar no espelho [os brasileiros] se enxergam sempre diferentes do que são. Ora mais portugueses, ora franceses, ora mais americanos, ora mais atrasados, ora até adiantados" (SCHWARCZ, STARLING, 2017, p. 18). Junto com o bovarismo, estaria outro vício de temperamento responsável pelo atraso: o "familismo", e novamente a referência é Sérgio Buarque de Holanda, que não é lido como "intérprete do Brasil", no sentido que os estudos sociais universitários atribuíram ao termo, mas sim como "historiador", ou "sociólogo", capaz de oferecer um diagnóstico preciso, e verdadeiro, da realidade nacional.

Como nossa República é frágil, ela se torna particularmente vulnerável ao ataque de seus dois principais inimigos: o patrimonialismo e a corrupção. O principal deles, o patrimonialismo, é resultado da relação viciada que se estabelece entre a sociedade e o Estado, quando o bem público é apropriado privadamente. Ou, dito de outra maneira, trata-se do entendimento, equivocado, de que o Estado é bem pessoal, "patrimônio" de quem detém o poder. E, apesar de o conceito de patrimonialismo parecer velho e em desuso, até superado, ele nunca se mostrou tão atual. (SCHWARCZ, 2019, p. 65)

Lilia Schwarcz define o patrimonialismo como a tese mais adequada para a compreensão do Brasil contemporâneo, colocando a si mesma como herdeira desse repertório. A principal referência é Sérgio Buarque de Holanda, mas ele não está só. A autora reconhece sua dívida também com Raymundo Faoro e Roberto Da Matta. A diferença com a leitura desenvolvida no livro "A elite do atraso" chama atenção, o que talvez explique o fato de Schwarcz, escrevendo depois do retumbante sucesso editorial do livro de Jessé Souza, tê-lo ignorado solenemente, não the dedicando sequer uma pálida citação em nota de rodapé. Os mais vendidos da historiografia comercial atualizam, e disputam, os topos do pensamento social brasileiro.

Presença mais cativa do que Lilia Schwarz no seleto grupo dos best-sellers somente Laurentino Gomes, que no período que examino neste artigo conseguiu emplacar quatro títulos na lista dos campeões de vendas: a trilogia “1808”, 1822” e “1889”, publicados, respectivamente, em 2007, 2010 e 2013, e o primeiro volume do “Escravidão”, publicado em 2019. A identidade autoral reivindicada por Laurentino Gomes não é a do historiador, mas sim a do jornalista, que checa com cuidado 
A mobilização das tópicas do pensamento social brasileiro na historiografia comercial consumida no Brasil em tempos de crise democrática (2013-2020)

Rodrigo Perez Oliveira

suas "fontes", divididas em dois grupos: as fontes de época, o "arquivo", e as fontes bibliográficas, representadas por importantes nomes da historiografia acadêmica, como Maria Odila dos Santos, Manolo Florentino, João Fragoso e Alberto da Costa e Silva. Assim, afirmando seu cuidado na verificação das fontes, que "caracteriza a boa prática do jornalismo investigativo", Gomes narra os eventos mais importantes da história nacional "com estilo atraente aos leitores que se interessam pelos acontecimentos do passado, mas não estão habituados nem dispostos a decifrar a rebuscada linguagem acadêmica” (GOMES, 2007, p. 19-20).

Em cada um dos seus quatro livros, Laurentino Gomes apresenta leitura específica do atraso nacional. Em “1808”, a transferência do Estado metropolitano para o território colonial, "evento único na história da Europa”, é definida como uma "uma fuga pura e simples, apressada, atabalhoada, sujeita a erros e improvisações", que teria “implantado no Brasil um aparelho burocrático inchado, pesado e disposto a ser terreno fértil para toda sorte de negociatas e corrupção, deixando marcas resistentes ao tempo no modo de proceder de muitos de nossos governantes" (GOMES, 2007, p. 82). O argumento principal da tese do patrimonialismo, que associa corrupção ao tamanho do Estado e à atuação dos políticos profissionais eleitos pelo voto popular, está diluída na crônica jornalística de Laurentino Gomes. O livro foi consumido por milhares de leitores, especialmente em junho de 2013, momento de ápice de seu sucesso comercial, e quando parte da sociedade brasileira estava nas ruas protestando, convencida de que o grande problema do Brasil é a corrupção praticada pela classe política (SINGER, 2013). Já em “1822”, o evento em tela é a independência, quando o autor localiza a fundação do Brasil "tal como nós conhecemos hoje", como uma "trama histórica que tinha tudo para dar errado" (GOMES, 2010, p. 8). O argumento central do livro diz que até às vésperas do "07 de setembro" não havia um projeto sólido para construção de um Estado independente de Portugal.

Foram o radicalismo e a falta de sensibilidade política das cortes constituintes portuguesas, pomposamente intituladas de "Congresso Soberano", que precipitaram a ruptura. Portanto, os brasileiros apenas se aproveitaram das fissuras abertas na antiga metrópole para executar um projeto que, a rigor, ainda não estava maduro. (GOMES, 2010, p. 10) 
A mobilização das tópicas do pensamento social brasileiro na historiografia comercial consumida no Brasil em tempos de crise democrática (2013-2020)

Rodrigo Perez Oliveira

O Estado nacional brasileiro é tratado como o resultado de uma articulação política um tanto improvisada, "mambembe", que triunfou mais por seus vícios do que por suas virtudes, já que o medo do caos social teria agregado as elites mais influentes na defesa da Monarquia, da integridade do território e da escravidão. O autor tenta convencer seu leitor de que estudar esse momento, as "origens do Brasil", é indispensável para a compreensão do "Brasil dos dias de hoje". No diagnóstico do autor, a forma como se deu a independência, efetivada para garantir a sobrevivência de uma Monarquia escravocrata, projetou sobre nós, brasileiros do presente, a sombra do atraso, que ganhou a forma de uma sociedade que ainda não conseguiu se construir como nação, ou, e aqui Laurentino Gomes cita José Bonifácio de Andrada e Silva (1763-1838), "amalgamar tanto metal heterogêneo em corpo sólido e político" (GOMES, 2010, p. 10).

A tese de que o legado da escravidão impediu a construção de uma comunidade nacional solidária no Brasil é reforçada em "Escravidão: volume 1", o livro mais recente de Laurentino Gomes. O volume é o primeiro de uma série de três livros a serem publicados até 2021, e que pretendem contar a história do Brasil a partir da experiência da escravidão, tratada como a origem do atraso que se perpetua até os dias atuais. Afirmando que a abolição da escravidão é um processo incompleto no Brasil, o autor acredita que estudar o assunto, melhor entendê-lo, é fundamental para a superação do atraso, algo que já vem sendo feito "por uma vasta produção literária e acadêmica com enfoques diferentes e, muitas vezes, conflitantes entre si” (GOMES, 2019, p. 35).

A relação agônica de Laurentino Gomes com o passado nacional também dá o tom do livro "1889", que começa com a afirmação de que o feriado de Quinze de novembro tem pouco prestígio no calendário cívico brasileiro, pois "ao contrário do Sete de Setembro, Dia da Independência, comemorado em todo o país com desfiles escolares e militares, o feriado da Proclamação da República é uma festa tímida, geralmente ignorada pela maioria das pessoas” (GOMES, 2013, p. 23). Diz o autor que "a julgar pela memória cívica nacional, o Brasil tem uma República malamada" (GOMES, 2013, p. 23). Isso se explicaria pela forma como se deu a implantação do regime republicano no país. A tese do livro já vem estampada na campa, na forma de subtítulo: a República teria sido o resultado das vacilações de 
A mobilização das tópicas do pensamento social brasileiro na historiografia comercial consumida no Brasil em tempos de crise democrática (2013-2020)

Rodrigo Perez Oliveira

um "Imperador cansado", das ambições de um "marechal vaidoso" e do ressentimento de um "professor injustiçado", sem que o "povo" tenha jamais tomado parte do processo como ator protagonista. Enquanto os propagandistas republicanos passaram toda a década de 1880 falando em "tirania" e "liberdade", o povo acompanhava com relativa indiferença os acontecimentos. A República no Brasil, segundo Laurentino Gomes, nasceu "sem povo". A tese está longe de ser uma novidade na história intelectual brasileira.

Poucos dias depois da Proclamação da República, ainda em novembro de 1889, o escritor paulista e ativista da restauração monárquica Eduardo Prado (18601901) publicou seus “Fastos da Ditadura Militar" na "Revista de Portugal”, dirigida por Eça de Queirós (1845-1900). Para Prado, a República havia sido resultado da "bacharelização do Exército brasileiro", que tomado por "ambições descabidas às instituições militares derrubou Monarquia à revelia do povo, e justamente no momento em que o trono era mais amado, em virtude do fim da escravidão" (PRADO, 2003, p. 43). A República brasileira já teria nascido maculada por um vício de origem, por um déficit democrático, sendo o resultado de uma "quartelada bacharelesca" comandada por "dois bacharéis ambiciosos e inescrupulosos": Benjamin Constant (1836-1891), o "professor injustiçado" do qual fala Laurentino Gomes, e Rui Barbosa.

As linhas gerais da tese de Eduardo Prado chegaram à historiografia especializada, especialmente aos estudos desenvolvidos por José Murilo de Carvalho"12. No livro "O teatro das sombras", publicado em 1980, Carvalho argumenta que na década de 1890 "era nítida e distância entre a representação e a opinião pública que, pela primeira vez, se organizou e se fez visível no movimento abolicionista” (CARVALHO, 2006, p. 411). Ressonando Prado, Carvalho diz que a Monarquia teria sido derrubada quando era mais popular, já que "a pressão imperial em favor da abolição final coincidia com a opinião pública”. Ironicamente, continua José Murilo de Carvalho, "o rei, no caso a princesa, estava ao lado da opinião do povo, perdendo com isto a legitimidade junto aos partidos e à elite política"

\footnotetext{
12 José Murilo de Carvalho é conhecedor e comentador da obra de Eduardo Prado. Se levarmos em conta o discurso que Carvalho proferiu na Academia de Brasileira de Letras em 2001, na ocasião das efemérides do centenário da morte do monarquista paulista, é também seu admirador.
} 
A mobilização das tópicas do pensamento social brasileiro na historiografia comercial consumida no Brasil em tempos de crise democrática (2013-2020)

Rodrigo Perez Oliveira

(CARVALHO, 2006, p. 411). A dimensão militar do 15 de novembro foi explorada pelo autor no livro "Forças armadas e a política no Brasil", publicado em 1977. Novamente, as semelhanças com as análises de conjuntura desenvolvidas por Eduardo Prado saltam aos olhos.

A escola militar, sobretudo após a entrada do positivismo, transformou-se num centro de estudos de matemática, filosofia e letras, mais do que de disciplinas militares. A influência positivista intensificou-se depois do ingresso de Benjamin Constant no quadro docente em 1872. Depoimentos de ex-alunos e o conteúdo das revistas publicadas pelos alunos denunciam a predominância de um ambiente muito distante do que seria de esperar numa instituição destinada a preparar técnicos em fazer guerra. (CARVALHO, 2005, p. 24-25)

A leitura crítica de José Murilo de Carvalho da Proclamação da República brasileira seria desenvolvida ainda em outros trabalhos, como no livro "Os Bestializados: o Rio de Janeiro e a República que não foi”, publicado em 1987, e no livro "A Formação das Almas: o imaginário da República no Brasil”, no qual o autor reforça a tese pradiana de que a República no Brasil nasceu com um vício de origem, maculada por um déficit democrático ${ }^{13}$. O argumento foi levado pelo próprio José Murilo de Carvalho às páginas da historiografia comercial, no livro sugestivamente intitulado "O pecado original da República", publicado em 2017 e que esteve entre os mais vendidos em janeiro de 2018. O livro reúne diversos textos publicados na imprensa e em veículos de divulgação, com o objetivo de colaborar para a compreensão dos "dilemas contemporâneos por qual passa a República brasileira”, nas palavras de Renato Lessa, que assina a orelha do volume. A crise do mensalão, a legislação eleitoral, a polarização PT x PSDB, a atuação do Supremo Tribunal Federal (STF) e o impeachment de Dilma Rousseff estão entre os assuntos abordados por José Murilo de Carvalho, todos eles interpretados à luz da tópica do "pecado original da República”.

\footnotetext{
3 Há na historiografia especializada interpretações que confrontam a tese pradiana/carvalhiana, como a desenvolvida por Maria Tereza Chaves de Mello, que apresenta o argumento de que "À monarquia, no final do Império, estava associado o atraso, o impedimento da modernização do país, diante do que a República aparecia como solução. Supomos, então, que a aceitação da República [e a ausência de defesa da Monarquia] deve ser explicada por uma disposição mental ao novo regime como decorrência da incorporação de uma nova cultura democrática e científica na década de 1880, tomando como recorte espacial a cidade do Rio de Janeiro em função de sua centralidade na vida do país" (MELLO, 2007, p. 11).
} 
A mobilização das tópicas do pensamento social brasileiro na historiografia comercial consumida no Brasil em tempos de crise democrática (2013-2020)

Rodrigo Perez Oliveira

Ainda estamos lutando com o problema de construir uma democracia inclusiva, capaz de sustentar governos representativos que possam combinar estabilidade institucional com implementação de políticas públicas voltadas para as necessidades da maioria dos representados. A ser correta a minha argumentação, seria plausível atribuir a instabilidade dos nossos governos no poder à incapacidade de processar a entrada do povo na política, mesmo que tardia. (CARVALHO, 2017, p. 26-27)

O "desde sempre" da República brasileira, o atraso, consiste, na visão de Carvalho, no esforço dos poderosos em erguer bloqueios que dificultam a efetiva participação do povo na política institucional. Foi isso que teria motivado os esquemas de corrupção chefiados pelos governos petistas, que tinham o objetivo de "comprar outras siglas", ao invés de governar com as bases da sociedade, como o partido havia prometido nas décadas de 1970, 1980 e 1990. A ação "olímpica” dos ministros do STF que, "ignorando o clamor popular", aceitaram os "embargos infringentes feitos pela defesa dos acusados no julgamento do mensalão", seria outro exemplo dessa "blindagem institucional ao povo". A legislação eleitoral que obriga o eleitor a votar em candidatos "em sua absoluta maioria corruptos", "dificultando a abstenção e o voto nulo" teria o objetivo de criar a "ficção de uma participação política que não se dá na prática institucional do poder”. Mas isso não significa que o povo, no cotidiano, seja incapaz de driblar a blindagem e se fazer ouvir pelos poderosos. Nesse sentido, as manifestações de junho de 2013, que teriam tido o objetivo de "fazer da República um regime de todos e para todos", e o apoio popular à Operação Lava-Jato, são colocados pelo autor em uma tradição de participação popular "para além do voto" que deita suas raízes nos primeiros anos da República, especificamente na Revolta da Vacina, na Guerra de Canudos e na simbologia oficial do regime, que precisou acolher valores populares, tanto na bandeira que trazia elementos estéticos do pavilhão monárquico, quanto na representação cristã de Tiradentes como herói cívico.

A “História da riqueza no Brasil", de Jorge Caldeira, foi publicado em 2017 e esteve no top ten em abril de 2018. O livro trata das contradições do capitalismo periférico brasileiro, mas numa chave interpretativa bastante diferente daquela que caracterizou o "radicalismo de classe média" e o "marxismo de matriz comunista", para nos mantermos próximos à nomenclatura proposta por Gildo Marçal Brandão. Tendo sido editor de poderosos veículos da imprensa brasileira, como o jornal 
A mobilização das tópicas do pensamento social brasileiro na historiografia comercial consumida no Brasil em tempos de crise democrática (2013-2020)

Rodrigo Perez Oliveira

"Folha de São Paulo" e a revista "Isto é", Caldeira é nome conhecido no mercado editorial por livros como "Mauá, empresário do império" (1995), "A nação mercantilista: ensaio sobre o Brasil" (1999) e "História do Brasil para empreendedores" (2009). Em todos esses textos, o autor aciona a conhecida tese que diz ser o Estado o responsável pelo atraso nacional, o grande obstáculo para o desenvolvimento do Brasil. Mas o faz com uma ligeira diferença em relação ao patrimonialismo.

O problema central, para Jorge Caldeira, não é exatamente a corrupção, mas sim a constante tendência do poder público em intervir na economia, sufocando a iniciativa privada e bloqueando o desenvolvimento capitalista autônomo. O argumento é reforçado no "História da riqueza no Brasil", em um ambicioso trabalhado de síntese histórica que promete corrigir os erros e as imprecisões acumulados ao longo do tempo que insistiram em pensar a economia brasileira a partir do mercado externo, como se não existisse no país um mercado interno pujante e capaz de servir como motor do desenvolvimento nacional. Segundo Mary Del Priore, que assina a apresentação do livro, Caldeira "explica a história do Brasil em nova chave, dialogando com a antropologia, a econometria e se valendo de vastos dados estatísticos", o que o possibilita, "por seu apuro metodológico e critério científico", superar clássicos do pensamento social brasileiro, como Gilberto Freyre, Sérgio Buarque de Holanda e Caio Prado Jr. O Livro, continua Del Priore, é uma "denúncia aos boicotes do poder público à ação dos empreendedores brasileiros", que não raro conseguiram "encontrar brechas que explicam os lampejos de progresso que, felizmente, aceleraram em alguns momentos de nossa história o desenvolvimento do país” (DEL PRIORE, 2017). No quadro pintado por Jorge Caldeira está, de um lado, o Estado pesado, arcaico, sufocante e desejoso de intervir no processo produtivo. Do outro, estão os empresários brasileiros ousados que insistem em resistir e acabam sendo os responsáveis pelo progresso nacional.

A noção de "economia de subsistência" está no centro da reflexão desenvolvida por Jorge Caldeira, que se diz interessado em estudar "as diversas formas como se deram as práticas de acumulação de bens e produção de riqueza na história do Brasil” (CALDEIRA, 2017, p. 18). A pretensão do autor, no entanto, é bem mais ambiciosa, e atravessada pelos conflitos políticos que marcaram o 
A mobilização das tópicas do pensamento social brasileiro na historiografia comercial consumida no Brasil em tempos de crise democrática (2013-2020)

Rodrigo Perez Oliveira

impeachment de Dilma Rousseff, em 2016, um dos momentos mais agudos da crise democrática. O "História da Riqueza no Brasil" endossa a acusação de que a Presidenta reeleita em 2014 teria praticado crimes contra as contas públicas, comprometendo a segurança fiscal do país. O dolo de Dilma Rousseff, no entanto, nada mais seria do que a manifestação da tendência intervencionista do poder público na economia, tratada pelo autor como passado que não passa, como o espectro que assombra o presente na forma de atraso atávico.

Isso não significa, entretanto, que toda a história brasileira tenha sido pautada por essa força de atraso. Houve momentos, argumenta Caldeira, em que o Estado foi reduzido aos "limites justos e ideais", deixando de "sufocar os atores econômicos internos". Na avaliação do autor, essa "era de ouro" da história do Brasil teria sido a década de 1990, quando o país era governado por Fernando Henrique Cardoso, do Partido da Social- Democracia Brasileira (PSDB). Esse teria sido o momento do "desencalhe econômico brasileiro". Caldeira elogia as privatizações, como a do sistema de telecomunicações, feita "justamente no período em que a internet e os celulares se tornaram os meios relevantes de comunicação", e a da Vale do Rio Doce, que deixou de ser "o braço provincial de um governo local”, para se tornar "uma grande empresa mundial de mineração". Assim, "à medida que se livrava dos esqueletos do passado e deixava de atuar em áreas nas quais não conseguiu ser empresário eficiente, o governo federal passou a dispor de mais recursos para cuidar das áreas prioritários" (CALDEIRA, 2017, p. 595).

A situação, lamenta o autor, retrocederia em 2003, com a posse de Lula, dando início ao "reencalhe". O atraso, novamente, "voltava a encalhar o Brasil". A situação melhoraria apenas em 2016, com a queda de Dilma e a posse de Temer, que "assumiu a presidência da República apresentando um plano chamado Ponte para o Futuro", prometendo "controlar os gastos do governo em um patamar aceitável e concentrar os investimentos no setor privado" (CALDEIRA, 2017, p. 599). O evento que foi visto por muitos como um golpe de Estado, foi tratado por Caldeira como um lampejo de esperança, como a brecha aberta para a superação do atraso e a retomada das boas práticas de governança desenvolvidas na década de 1990. Se Jessé Souza foi o best-seller petista nesses anos de crise, Jorge Caldeira apresentou ao "grande público" uma interpretação tucana da história do Brasil. 
A mobilização das tópicas do pensamento social brasileiro na historiografia comercial consumida no Brasil em tempos de crise democrática (2013-2020)

Rodrigo Perez Oliveira

Conclusão: breve reflexão sobre ideias políticas e crise democrática no Brasil contemporâneo

$\mathrm{Na}$ segunda quinzena de junho de 2013, diversos institutos de pesquisa enviaram seus técnicos às ruas para tentar responder perguntas que até hoje suscitam reflexão e discordâncias no debate político nacional: o que estava acontecendo? Por que, em um momento no qual o país apresentava índices socioeconômicos relativamente positivos $^{14}$, parte considerável da população se insurgiu contra o governo instituído? Essas questões já foram bastante exploradas pelos estudos especializados, que apresentam interpretações distintas, muitas vezes opostas entre si, o que demonstra como o significado das "jornadas de junho de 2013" ainda está sendo disputado (RAUTER, 2020).

O DataFolha entrevistou 766 pessoas que participaram dos atos realizados em São Paulo no dia 17 de junho15 e 566 que estiveram presentes em 20 de junho ${ }^{16}$. No Rio de Janeiro, a pesquisa foi feita pelo instituto Plus Marketing, também em 20 de junho, com 498 manifestantes. No mesmo dia, O IBOPE entrevistou 2002 pessoas envolvidas em protestos populares que aconteceram em oito capitais (São Paulo, Rio de Janeiro, Belo Horizonte, Porto Alegre, Recife, Fortaleza, Salvador e Brasília). Os dados disponíveis, segundo André Singer (2013), mostram que o manifestante médio de junho de 2013 era jovem, com menos de 25 anos, com alto grau de letramento, já que portador de diploma universitário, e com renda familiar intermediária, entre dois e dez salários mínimos. Poucos dias antes, no começo de junho, o Datafolha havia realizado uma de suas pesquisas rotineiras sobre a popularidade do governo. A aprovação de Dilma Rousseff caiu sensivelmente entre a população com renda mais alta, baixando de 67\% (número aferido em março) para 43\%. Ao que tudo indica, a insatisfação com a administração petista começou na classe média, motivada, segundo o economista André Lara Resende, por demandas "pós-materiais".

\footnotetext{
14 Segundo o IBGE, em junho de 2013, a inflação era de 0,4\%, estando em 6,7\% no acumulado para o ano, bem próximo ao teto da meta estabelecida pelo Banco Central. Já o desemprego, também com números do IBGE, estava em 6\%, um dos menores índices da série histórica. Em 2012, O PIB havia crescido 1,4\%, bem menos que os melhores anos das administrações petistas, mas longe da recessão que o país viveria nos anos seguintes.

${ }^{15}$ Os dados dessa pesquisa podem ser consultados no site do instituto, www.datafolha.com.br.

${ }^{16}$ Os dados dessa pesquisa foram publicados pelo jornal "Folha de São Paulo", em 22 de junho de 2013.
} 
A mobilização das tópicas do pensamento social brasileiro na historiografia comercial consumida no Brasil em tempos de crise democrática (2013-2020)

Rodrigo Perez Oliveira

A relação entre renda e bem-estar só é claramente positiva até um nível relativamente baixo de renda, capaz de atender às necessidades básicas da vida. A partir daí, o aumento do bem-estar está associado ao que se pode chamar de qualidade de vida, cujos elementos fundamentais são o tempo com a família e os amigos, o sentido de comunidade e confiança nos concidadãos, a saúde e a ausência de estresse emocional. (RESENDE, 2013)

O autor busca o conceito "classe média pós-materialista nos estudos desenvolvidos pelo cientista político norte-americano Ronald Iglenhart, argumentando que esse grupo costuma ser mais sensível aos escândalos de corrupção, como os que estavam na agenda nacional nos meses anteriores às “jornadas", quando o julgamento do "mensalão"17 foi amplamente coberto pela imprensa. Esse grupo social, continua Resende, estava manifestando a insatisfação com o Estado, que teria se tornado "inútil sorvedouro de recursos, com seus 39 ministérios ausentes e inoperantes, seu Legislativo, do qual só se tem más notícias e frustrações e seu Judiciário pomposo e exasperadoramente lento" (RESENDE, 2013). A pesquisa qualitativa desenvolvida pelo lbope em 20 de junho parece endossar a hipótese: 65\% dos manifestantes entrevistados desejaram "mudanças no ambiente político", e 50\% diziam ser a corrupção o principal problema do país. Temos aqui interpretação da realidade segundo a qual os "hospitais padrão FIFA" e punição exemplar aos corruptos simbolizam a modernização do Brasil" (SINGER, 2013, p. 38).

A vitória de Dilma Rousseff nas eleições presidenciais de 2014 não acalmou a situação ${ }^{19}$. A insatisfação social se tornou ainda mais aguda em 2015 e 2016, anos marcados por constante agitação social e intensa instabilidade política. O signo do atraso nacional continuou sendo mobilizado nas ruas. Em 15 de março, aconteceu o maior ato dessa segunda onda de protestos populares e, novamente, institutos de pesquisa tentaram mapear o perfil dos manifestantes e os motivos de sua

\footnotetext{
17 Entre agosto e dezembro de 2012, o noticiário político nacional diariamente abordou o trâmite da ação penal 470 no pleno do Supremo Tribunal Federal, o que provocou grande comoção, transformando Joaquim Barbosa, então Presidente da corte, em herói nacional, antecipando em muitos aspectos a pulsão punitivista que dois anos depois alimentaria o lavajatismo.

${ }^{18}$ Estava sendo iniciada na época a programação dos grandes eventos que o Brasil sediaria até 2016: em junho de 2013, aconteceu a Copa das Confederações, entre junho e julho de 2014 foi a vez da Copa do Mundo. O ciclo se encerrou em agosto de 2016, com a realização das Olimpíadas.

19 Nas eleições presidenciais de 2014, Dilma Rousseff (PT) venceu Aécio Neves (PSDB) por uma diferença de apenas 3,28\% dos votos válidos, naquela que foi a disputa mais apertada da história da "Nova República" brasileira, instituída pela constituição de 1988
} 
A mobilização das tópicas do pensamento social brasileiro na historiografia comercial consumida no Brasil em tempos de crise democrática (2013-2020)

Rodrigo Perez Oliveira

insatisfação. Datafolha e Ibope em São Paulo, Rio de Janeiro e Belo Horizonte; Ibope em Recife, Salvador e Brasília; Instituto Index em Porto Alegre e Santa Catarina. A cientista política Helcimara Telles (2015) tabulou os números, demonstrando que, com algumas variações regionais que não comprometem a visão geral do cenário, o perfil médio do manifestante de 2015 é um tanto diferente do de 2013: mais rico (renda superior a dez salários mínimos), mais velho (idade superior a 35 anos), porém igualmente letrado, pois também portador de diploma universitário. A agenda programática é parecida, já que 66\% dos entrevistados afirmaram ser a corrupção a fonte dos problemas brasileiros, e demandaram o fim do governo petista e reformas político/administrativas que "punissem políticos corruptos e diminuíssem a quantidade de ministérios do governo" (TELLES, 2015, p. 23).

É importante lembrar que o antipetismo não estava ocupando sozinho as ruas. Com pouca cobertura midiática e com pequena capacidade de mobilização, centrais sindicais, como a Central Única dos Trabalhadores (CUT), e movimentos sociais organizados, como a União Nacional dos Estudantes (UNE) e o Movimento dos Trabalhadores Rurais Sem Terra (MST), acionaram suas bases para defender o mandato de Dilma Rousseff. Os institutos de pesquisa não tiveram interesse em entrevistar os apoiadores do governo, mas provavelmente a interpretação da realidade que movia esses grupos era diferente daquela que inspirava os atos oposicionistas. Se tivessem sido perguntados, os apoiadores da Presidenta certamente não diriam ser a corrupção o principal fator do atraso nacional, mas sim a sobrevivência de um passado projetado no presente na forma uma sociedade estruturalmente discriminatória com as minorias e violenta com os pobres. Provavelmente, demandariam o aprofundamento das políticas públicas reparatórias que já vinham sendo desenvolvidas pelas administrações petistas desde o início do século, ao invés de exigir o fim do governo e a diminuição no número de ministérios.

Corrupção praticada pela classe política e potencializada pelo tamanho do Estado. Racismo e classismo herdados dos tempos da escravidão e conservados por uma República oligárquica e por experiências ditatórias que não construíram uma democracia social plena no Brasil. Nos últimos anos, leituras do atraso nacional desenvolvidas pelos intérpretes do Brasil ao longo do século XX e 
A mobilização das tópicas do pensamento social brasileiro na historiografia comercial consumida no Brasil em tempos de crise democrática (2013-2020)

Rodrigo Perez Oliveira

mobilizadas pelos best-sellers da historiografia comercial consumida a partir de 2013 parecem ter sido capazes de inspirar ações políticas efetivas na sociedade civil. Não estou afirmando que os brasileiros diretamente envolvidos nos conflitos em tela leram, no sentido literal do verbo, os autores que examinei neste artigo. Se bem que não seria nenhum absurdo sugerir que alguns, sim, leram, tendo em vista os números que os best-sellers alcançaram no mercado editorial e o grau de letramento dos manifestantes detectado pelos institutos de pesquisa.

Além disso, basta lembrarmos das "Coleções Brasilianas", organizadas pela Companhia Editorial Nacional e que entre as décadas de 1940 e 1960 publicaram textos de ensaístas como Gilberto Freyre e Sérgio Buarque de Holanda (DUTRA, 2006), para sabermos que não é de hoje que as meta-interpretações do Brasil interessam bastante aos leitores não especializados. De todo modo, não é necessário ler determinado autor para se deixar inspirar por suas ideias. Com o passar do tempo, por motivos variados, alguns repertórios circulam no tecido social como se fossem "energia" fluindo e refluindo, de um lado a outro (GALAGHER; GREENBLATT, 2005), constituindo-se naquilo que, na falta de um termo melhor, podemos chamar de "senso comum".

Nas crises estruturais, quando a área do consenso social se estreita na mesma proporção em que o território do debate público se alarga, a sociedade costuma se olhar no espelho, querendo entender como chegou naquele ponto, por que colapsou de tal maneira. As teses que prometem respostas para essas angústias existenciais coletivamente compartilhadas tendem a atrair o interesse de uma parcela da população que, em tempos normais, pouca atenção dedicaria aos assuntos políticos. As crises politizam a sociedade, para o bem e para o mal. 0 mercado editorial, naturalmente, está atento a essa demanda ampliada, assim como os intelectuais que, vindo de todos os lados do espectro ideológico, tentam interferir no jogo político, disputando o sentido da realidade. De antemão, não há como saber como o jogo acaba. Certeza mesmo é que aqueles que não entrarem em campo perderão por W.O. 
A mobilização das tópicas do pensamento social brasileiro na historiografia comercial consumida no Brasil em tempos de crise democrática (2013-2020)

Rodrigo Perez Oliveira

\section{Referências}

CALDEIRA, Jorge. História da riqueza no Brasil. Rio de Janeiro: Estação Brasil, 2917.

CARITAT, Antoine-Nicolas. O progresso do espírito humano. In: GARDNER, Patrick. Teorias da história. Lisboa: Fundação Calouste Gulbenkian, 1995.

CARVALHO, José Murilo de. O pecado original da República. Rio de Janeiro: Bazar do Tempo, 2017.

CARVALHO, José Murilo de. A Construção da ordem/ o teatro das sombras.

Civilização Brasileira: Rio de Janeiro, 2006.

CARVALHO, José Murilo de. Forças armadas e política no Brasil. Rio de Janeiro: Jorge Zahar Ed., 2005.

ENGELS, Friedrich; MARX, Karl. O manifesto comunista. São Paulo: Ridendo Castigar Moraes, 1999.

GOMES, Laurentino. 1808. São Paulo: Editora Planeta, 2009.

GOMES, Laurentino. 1822. São Paulo: Editora Nova Fronteira, 2010.

GOMES, Laurentino. 1889. São Paulo: Editora Globo, 2013.

GOMES, Laurentino. Escravidão (Volume 1). Rio de Janeiro: Globo Livros, 2019.

NARLOCH, Leandro. Guia politicamente incorreto da história do Brasil. São Paulo: Ed. Leya, 2009.

PRADO, Eduardo. Fastos da ditadura militar no Brasil. São Paulo: Martins Fontes, 2003.

SCHWARCZ, Lilia Moritz; STARLING, Heloisa. Brasil: uma biografia. São Paulo: Companhia das Letras, 2015.

SCHWARCZ, Lilia Moritz. Sobre o autoritarismo brasileiro. São Paulo: Companhia das Letras, 2019.

SOUZA, Jessé. A elite do atraso: da escravidão à Lava Jato. São Paulo: Editora Leya, 2017. 
A mobilização das tópicas do pensamento social brasileiro na historiografia comercial consumida no Brasil em tempos de crise democrática (2013-2020)

Rodrigo Perez Oliveira

ALBIERI, Sara; GLEZER, Raquel. O campo da história e as 'obras fronteiriças': algumas observações sobre a produção historiográfica brasileira e uma proposta de conciliação. Revista IEB, São Paulo, n. 48, p. 13-30, 2009.

ARENDT, Hannah. Da revolução. São Paulo: Editora Ática, 1998.

ABREU, João Capistrano de. Necrológio de Francisco Adolfo de Varnhagen. Jornal do Comércio, São Paulo, p. 01-02, 1878.

ALONSO, Ângela. Ideias em movimento: a geração de 1870 na crise do Brasil Império. São Paulo: Paz e Terra, 2002.

BARBOZA FILHO, Ruben. A modernização brasileira e o nosso pensamento político. Perspectivas, São Paulo, v. 37, p. 15-64, jan./jun. 2010.

BEISER, Frederick C. German idealism: the struggle against subjectivism, 1781-1801. Cambridge: Harvard University Press, 2002.

BINOCHE, Bertrand. Les trois sources des philosophies de l'histoire. Paris: PUF, 1994.

BRANDÃO, Gildo Marçal. Linhagens do pensamento político brasileiro. Dados: Revista de Ciências Sociais, Rio de Janeiro, v. 48, n. 02, p. 231-269, 2005.

BRANDÃO, Gildo Marçal. A teoria política é possível? Revista Brasileira de Ciências Sociais, São Paulo, v. 13, n. 36, 1998.

CASIMIRO, Paulo Henrique; LYNCH, Christian Edward Cyril. Wanderley Guilherme dos Santos, modelo de intelectual. São Paulo: Nexo Jornal, 2019. Disponível em: https://www.nexojornal.com.br/ensaio/2019/10/29/Wanderley-Guilherme-dosSantos-modelo-de-intelectual-p\%C3\%BAblico. Acesso em: 24 set. 2020.

DARDOT, Pierre. LAVAL, Christian. A nova razão do mundo: ensaio sobre a sociedade neoliberal. São Paulo: Boitempo, 2016.

DUTRA, Eliana de Freiras. A nação dos livros: a biblioteca ideal na coleção Brasiliana. In: DUTRA, Eliana de Freitas.; MOLLIER, Jean-Yves. Política, nação e edição: o lugar dos impressos na construção da vida política- Brasil, Europa e Américas nos séculos XVIII e XX. São Paulo: Anablumme, 2006.

FRANZINI, Fabio. A década de 1930, entre a memória e a história da historiografia. In: PEREIRA DAS NEVES, Lucia M. B; GUIMARÃES, Lucia. M. P; GONÇALVES, Márcia; GONTIJO, Rebeca (orgs.). Estudos de historiografia brasileira. Rio de Janeiro:

Editora da Fundação Getúlio Vargas, 2011. 
A mobilização das tópicas do pensamento social brasileiro na historiografia comercial consumida no Brasil em tempos de crise democrática (2013-2020)

Rodrigo Perez Oliveira

GADAMER, Hans George. O problema da consciência histórica. Rio de Janeiro: Ed. FGV, 2006.

GALLAGHER, Catherine; GREENBLATT, Stephen. A prática do novo historicismo. Bauru: EDUSC, 2005.

GUERRA, Roberto Rodrigues. El liberalismo conservador contemporâneo. Santa Cruz de Tenertie: Universidade de La Laguna, 1998.

HAMBURGUER, Esther. Telenovelas e interpretação do Brasil. Lua Nova, São Paulo, n. 82, p. 61-86, 2011.

HESKETH, Ian. Diagnosing Froude's disease: boundary work and the discipline of history in late-victorian britain. History and Theory, 47, p. 373-395, out. 2008.

GUMBRECHT, Hans Ulrich. Modernização dos sentidos. São Paulo: Ed 34, 2010.

KOSELLECK, Reinhart. Futuro Passado: contribuição à semântica dos tempos históricos. Rio de Janeiro: ContraPonto, 2006.

LAMOUNIER, Bolivar. Formação de um pensamento político autoritário na Primeira República: uma interpretação. In: FAUSTO, Boris (org.). O Brasil Republicana/ história geral da civilização brasileira. Rio de Janeiro: Bertrand Brasil, 2007. Tomo III, v. 2. p. 345-374.

LYNCH, Christian Edward Cyril. Por Que Pensamento e Não Teoria? A Imaginação Político-Social Brasileira e o Fantasma da Condição Periférica (1880-1970). Dados, Revista de Ciências Sociais, Rio de Janeiro, v. 56, n. 4, p. 727-767, 2013.

LYNCH, Christian Edward Cyril. Cartografia do pensamento político brasileiro: conceito, história, abordagens. Rev. Bras. Ciênc. Polít. [online], Rio de Janeiro, n.19, p.75-119, 2016.

LOUREIRO, Isabel; SINGER, André (orgs.). As contradições do lulismo. São Paulo: Boitempo, 2016.

LUKACS, Georg. A alma e as formas. Belo Horizonte: Autêntica Editora, 2015.

MANNHEIM, Karl. Conservative thought. Londres: ED P\&C, 1987

MELLO, Maria Tereza Chaves de. A República consentida. Rio de Janeiro: FGV, 2007. 
MIGNOLO, Walter. Desobediência epistêmica: a opção descolonial e o significado de identidade em política. Cadernos de Letras da UFF, Niterói, n. 34, p. 287-324, 2008. Dossiê: Literatura, língua e identidade

NICOLAZI, Fernando. Raízes do Brasil e o ensaio histórico: da história filosófica à síntese sociológica (1836-1936). Revista Brasileira de História, São Paulo, v. 36, n. 73, p. 89-110, 2016.

PEREZ, Rodrigo. Por que vendem tanto? O consumo de historiografia comercial no Brasil em tempos de crise (2013-2019). Revista Transversos, Rio de Janeiro, n. 18, p. 64-85, 2020.

QUIJANO, Anibal. Colonialidade, modernidade e racionalidade. In: BONILLO, Heraclio (org.). Los conquistados. Bogotá: Mundo Ediciones: FLACSO, 1992. p. 437449 .

RAUTER, Luísa. As temporalidades do evento junho de 2013. In: OLIVEIRA, Rodrigo Perez; PINHA, Daniel (orgs.). Tempos de crise: ensaios de história política. Rio de Janeiro: Ed. Autografia, 2020. p. 150-180.

RESENDE, André Lara. O mal-estar contemporâneo. Valor econômico, São Paulo, 05 jul. 2013. Disponível em:

https://valor.globo.com/eu-e/coluna/o-mal-estar-contemporaneo.ghtml. Acesso em: 14 out. 2020.

RICUPERO, Bernardo. Sete lições sobre as interpretações do Brasil. São Paulo: Alameda, 2011.

SANTOS, Wanderley Guilherme dos. A democracia impedida: o Brasil no século XXI. Rio de Janeiro: FGV, 2017.

SANTOS, Wanderley Guilherme dos. A imaginação político-social brasileira. Dados, Revista de Ciências Sociais, Rio de Janeiro, n. 2-3, p. 182-93, 1967.

SINGER, André. Brasil, junho de 2013: classes e ideologias cruzadas. Novos Estudos, São Paulo, n. 97, nov. 2013.

SOUZA, Cláudio Andre. Antipetismo e ciclos de protestos no brasil: uma análise das manifestações ocorridas em 2015. Em Debate, Belo Horizonte, v. 8, n. 3, p. $35-$ 51, maio 2016. 
TELLES, Helcimara. Corrupção, legitimidade democrática e protestos: o boom da direita na política nacional? Revista Interesse Nacional, São Paulo, Ano 8, n. 30, p. 70-97, jul./set. 2015.

TELLES, Helcimara. Corrupção, antipetismo e nova direita: elementos da crise político-institucional. Revista GVExecutivo, São Paulo, v.14, n.2, p. 30-57, jul./dez. 2015b.

VIANNA, Luiz Werneck. A revolução passiva: iberismo e americanismo no Brasil. Rio de Janeiro: Ed. Renavan, 1997. 